\title{
UJI DAYA HAMBAT SEDIAAN SABUN CAIR EKSTRAK DAUN PALA (Myristica fragrans houtt) TERHADAP Propionibacterium acnes dan Staphylococcus aureus
}

\author{
Atika Pratiwi $^{1}$, Ella Noorlaela ${ }^{1}$, Siti Mahyuni $^{*}$ \\ ${ }^{1}$ Program Studi Farmasi FMIPA Universitas Pakuan, Bogor \\ "e-mail: s.mahyuni@yahoo.com
}

diterima: 20 Juli 2019; direvisi:22 Agustus 2019; disetujui: 3 September 2019

\begin{abstract}
ABSTRAK
Bakteri penyebab jerawat diantaranya Staphylococcus aureus dan Propionibacterium acnes. Daun pala merupakan tanaman yang mengandung zat antibakteri yang dapat menghambat pertumbuhan bakteri. Tujuan dari penelitian ini adalah membuat sediaan sabun dari ekstrak daun pala serta mengetahui formula yang paling efektif dalam menghambat pertumbuhan bakteri P.acnes dan Staphylococcus aureus. Daun pala diekstraksi menggunakan metode maserasi dengan pelarut etanol $96 \%$. Sediaan sabun cair dibuat sebanyak 4 formula. Uji aktivitas antibakteri dilakukan dengan metode dilusi untuk KHM dan metode difusi cakram untuk menentukan LDH sediaan sabun cair. Berdasarkan uji aktivitas antibakteri ekstrak etanol 96\% daun pala memiliki kemampuan menghambat pertumbuhan bakteri Staphylococcus aureus dengan nilai KHM pada konsentrasi 0,5\% dan negatif pada Propionibacterium acnes. Sediaan

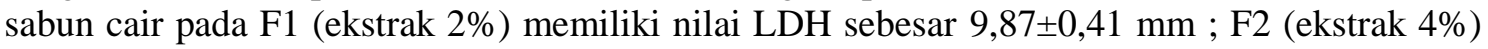
memiliki nilai $\mathrm{LDH}$ sebesar 10,50 $\pm 0,35 \mathrm{~mm}$; F3 (ekstrak 8\%) memiliki nilai LDH sebesar

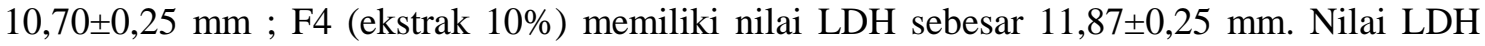
paling tinggi yaitu F4 dengan konsentrasi ekstrak 10\%, LDH F4 merupakan formula yang memiliki aktivitas antibakteri yang paling mendekati LDH kontrol positif JF Sulfur yang memiliki nilai $\mathrm{LDH}$ sebesar $13,25 \pm 0,25 \mathrm{~mm}$.
\end{abstract}

\section{Kata Kunci: Ekstrak Daun Pala, P.acnes, Sabun Cair dan S.aures}

\section{LIABILITY TESTS OF PALA LEAVES EXTRACT LIQUID SOAP (Myristica fragrans houtt) ON Propionibacterium Acnes AND Staphylococcus aureus}

\begin{abstract}
Bacteria that cause acne include Staphylococcus aureus and Propionibacterium acnes. Nutmeg leaves are plants that contain antibacterial substances that can inhibit bacterial growth. The purpose of this study is to make soap preparations from nutmeg leaf extracts and find out the formula that is most effective in inhibiting the growth of P.acnes and Staphylococcus aureus bacteria. Nutmeg leaves were extracted using maceration method with $96 \%$ ethanol solvent. Liquid soap preparations are made in 4 formulas. Antibacterial activity test was carried out by the dilution method for MIC and disk diffusion methods to determine LDH liquid soap preparations. Based on the test of the antibacterial activity of $96 \%$ ethanol extract, nutmeg leaves have the ability to inhibit the growth of Staphylococcus aureus with a MIC value at a concentration of $0.5 \%$ and negative on Propionibacterium acnes. Liquid soap preparations in F1 (extract 2\%) have LDH values of $9.87 \pm 0.41 \mathrm{~mm}$; F2 (extract 4\%) has an LDH value of $10.50 \pm$ $0.35 \mathrm{~mm}$; F3 (extract 8\%) has an LDH value of $10.70 \pm 0.25 \mathrm{~mm}$; F4 (extract 10\%) has an LDH value of $11.87 \pm 0.25 \mathrm{~mm}$. The highest $\mathrm{LDH}$ value is $\mathrm{F} 4$ with a concentration of $10 \%$ extract, LDH F4 is a formula that has the most antibacterial activity approaching LDH positive control JF Sulfur which has an LDH value of $13.25 \pm 0.25 \mathrm{~mm}$
\end{abstract}

Key words: Liquid Soap, Nutmeg Leaf Extract, Propionibacterium acnes, Staphylococcus aureus 


\section{PENDAHULUAN}

Jerawat atau acne vulgaris yang biasa dikenal sebagai penyakit kulit adalah keadaan tidak normal pada kulit yang menginfeksi kira-kira $80 \%$ yang berusia antara 11 dan 30 tahun tanpa melihat dari jenis kelamin ataupun ras (Dipiro et al., 2009). Bakteri penyebab jerawat terdiri dari Propionibacterium acnes (Chomnawang et al., 2007), Staphylococcus aureus (Sarlina et al., 2017), Staphylococcus epidermidis (Suryana et al., 2017).

Daun pala merupakan salah satu dari bagian tanaman pala yang belum banyak dimanfaatkan. Kandungan yang terdapat pada daun pala diantaranya : saponin, triterpenoid, tanin dan flavonoid yang dapat dikembangkan dalam berbagai bidang industri, misalnya : pangan, kosmestik dan farmasi (Ginting et al., 2014). Senyawa yang diduga sebagai antibakteri yaitu senyawa flavonoid dan terpenoid (Poeloengan, 2010).

Berdasarkan penelitian Rizal (2017), ekstrak etanol daun pala mempunyai aktivitas antibakteri terhadap Staphylococcus aureus pada konsentrasi $0,5 \%$ dengan diameter daerah hambat sebesar 6,46 $\mathrm{mm}$ dan efektif pada konsentrasi $6 \%$ dengan diameter daerah hambat sebesar 14,06 mm. Menurut Parekh (2006), diameter daerah hambat antibakteri yang paling efektif terhadap uji antibakteri adalah $14 \mathrm{~mm}$.

Bentuk sediaan yang dapat membantu menjaga kesehatan kulit adalah sabun. Sabun merupakan produk yang dihasilkan dari proses reaksi kimia antara asam lemak dengan basa kuat yang dapat mencuci atau membersihkan kotoran. Sabun dibagi menjadi 2 jenis yaitu sabun padat dan sabun cair (Hernani et al., 2010).

\section{BAHAN DAN METODE \\ Bahan dan Alat}

Bahan yang digunakan dalam penelitian ini adalah Daun Pala (Myristica fragrans houtt), etanol 96\% (Merck®) sediaan sabun cair JF Sulfur yang ada dipasaran, asam sitrat, sodium lauril sulfat (Brataco $\left.{ }^{\circledR}\right), \mathrm{NaCl}$
(Brataco $\left.{ }^{\circledR}\right)$, propilen glikol (Brataco $\left.{ }^{\circledR}\right)$, tryptic soy agar (TSA), tryptic soy broth (TSB), brain heart infusion (BHI), isolat Staphylococcus aureus, isolat Propionibacterium acnes, aquadest dan dimethyl sulfoxide (DMSO) $1 \%$.

Alat yang digunakan dalam penelitian ini adalah timbangan analitik (And®), rak tabung, batang pengaduk, tabung reaksi (Pyrex®), cawan penguap, jarum ose, labu ukur, autoclaf, jangka sorong, cawan petri (Pyrex $\left.{ }^{\circledR}\right), \mathrm{pH}$ meter, penangas, inkubator, pipet tetes, erlenmeyer (Pyrex $\AA)$, kertas cakram, kapas, kurs, tanur (Ney®), corong, ayakan mesh 40, micro pipet, kertas saring, kain batis, spirtus, , tip pipet mikro dan alat gelas lainnya untuk analisis.

\section{Metode}

\section{Pengumpulan Bahan Baku}

Daun yang digunakan adalah daun yang sudah tua (siap panen). Kemudian dilakukan determinasi tanaman (Bahan Baku) guna memastikan bahan baku yang digunakan adalah bahan baku yang seragam dan benar, determinasi tanaman ini dilakukan di Lembaga Ilmu Pengetahuan Indonesia (LIPI) Komplek CSC - LIP JL. Raya bogor Km 46, cibinong 16911 Bogor, Jawa barat, Indonesia.

\section{Pembuatan Serbuk Simplisia}

Daun pala segar dibersihkan dari kotoran yang menempel dengan menggunakan air bersih yang mengalir (sortasi basah), kemudian ditiriskan untuk menghilangkan air dari sisa-sisa pencucian. Daun yang telah bebas air dari pencucian dan bersih dikeringkan dengan oven pada suhu $50^{\circ} \mathrm{C}$ selama 3-4 hari (Depkes RI,1985). Setelah kering, selanjutnya digiling menggunakan grinder sampai menjadi serbuk kemudian diayak menggunakan ayakan no 40, lalu ditimbang dan disimpan dalam wadah bersih dan tertutup rapat.

\section{Pembuatan Ekstrak}

Sebanyak 800 gram serbuk simplisia daun pala dimaserasi dengan pelarut etanol 96\% sebanyak 75 bagian, dengan 
perbandingan $1: 10$. Pelarut yang digunakan adalah etanol $96 \%$ sebanyak $8000 \mathrm{ml}$. Pelarut dibagi menjadi 3 bagian, pada maserasi pertama sebanyak $3000 \mathrm{ml}$, maserasi kedua sebanyak $3000 \mathrm{ml}$, dan maserasi ketiga sebanyak $2000 \mathrm{ml}$. serbuk dimaserasi dengan etanol 96\% selama 24 jam, setiap 6 jam sekali dikocok selama 15 menit, setelah 24 jam filtrat dipisahkan menggunakan kain batis. Residu dimaserasi kembali dengan menggunakan proses yang sama seperti sebelumnya. Filtrat didiamkan selama semalam (dienaptuangkan) untuk menghasilkan filtrat 1 , filtrat 2 , filtrat 3 dan hasil residu dibuang. Hasil filtrat dikeringkan dengan Vaccum dry sampai menjadi ekstrak kering.

\section{Penetapan Kadar Air}

Penentuan kadar air simplisia dan ekstrak dilakukan dengan cara gravimetri. Ditimbang sebanyak 2-3 gram sampel dengan teliti. Dimasukan kedalam cawan uap yang sudah ditara kedalam oven $105^{\circ} \mathrm{C}$ selama 10 menit, diuapkan didalam oven $105^{\circ} \mathrm{C}$ hingga berat konstan (Depkes,2000). Penetapan kadar air bertujuan untuk memberikan batasan mineral tentang besarnya kandungan air didalam bahan hal ini terkait dengan adanya kontaminan serta kemurnian dalam simplisia (Depkes RI, 2000).

\section{Penetapan Kadar Abu Total}

Bahan uji ditimbang 2-3 gram, kemudian dimasukan kedalam krus silikat yang telah dipijarkan pada suhu $\pm 600^{\circ} \mathrm{C}$ dalam tanur kemudian ditara, diratakan dan dipijar perlahan-lahan hinga arang habis, kemudian didinginkan dan ditimbang hingga bobot konstan. Jika dengan cara ini arang tidak dapat dihilangkan, maka dapat ditambahkan dengan air panas, diaduk, dan disaring melalui kertas saring bebas abu. Dipijarkan sisa dan kertas saring dalam krus yang sama. Filtrat dimasukan kedalam krus diuapkan dan dipijar hingga bobot tetap, kemudian ditimbang.

\section{Analisis Fitokimia \\ Identifikasi Alkaloid}

Ekstrak diambil 0,1 gr kemudian ditambah dengan $5 \mathrm{ml}$ klorofom dan 3 tetes amoniak. lalu dibagi menjaditiga tabung yang masing-masing ditambah pereaksi dragendrof, mayer dan wagner. Alkaloid pada sampel ditandai dengan adanya endapan putih pada pereaksi mayer, endapan merah pada pereaksi dragendrof dan endapan cokelat pada pereaksi wagner (Hanani,2015).

\section{Identifikasi Flavonoid}

Ekstrak diambil sebanyak 0,1 gr dan dimasukan kedalam tabung reaksi, serbuk magnesium 0,1 gr dan amil alkohol 0,4 ml ditambahkan kedalam tabung reaksi. alkohol sebanyak $4 \mathrm{ml}$ ditambahkan dan dicampur hingga homogen. reaksi positif flavonoid ditunjukan dengan terbentuknya warna merah, kuning atau jingga pada lapisan amil alkohol (Hanani, 2015).

\section{Identifikasi Saponin}

Ekstrak diambil 0,015 gr dimasukan pada tabung reaksi. ditambahkan aquadest panas sebanyak $10 \mathrm{ml}$ dan dikocok selama 5 menit, diamkan selama 5 menit. hasil positif dari adanya saponin adalah terbentuk busa tebal $\pm 1-10 \mathrm{~cm}$ yang konstan (Hanani, 2015).

\section{Identifikasi Tanin}

Ekstrak dimasukan kedalam tabung reaksi ditambahkan $\mathrm{FeCl}_{3}$ sampai terbentuk warna hijau-biru sebagai uji pendahuluan adanya senyawa tanin. Pada tabung reaksi yang lain, ekstrak dilarutkan dengan sedikit aquadest kemudian dipanaskan dipenangas air lalu diteteskan larutan gelatin 1\% (1:1). Hasil positifnya terbentuk endapan putih (Hanani, 2015).

\section{Identifikasi Steroid dan Triterpenoid}

Ekstrak diambil sebanyak 0,1 gr dan dipindahkan kedalam drop plate. larutan acetat anhidrat sebanyak 3 tetes dan larutan $\mathrm{H}_{2} \mathrm{SO}_{4}$ pekat 1 tetes ditambahkan pada ekstrak. hasil positif pada pengujian ini 
yaitu terbentuk warna merah yang menandakan adanya terpenoid dan warna hijau menandakan adanya steroid (Hanani, 2015).

\section{Uji Aktivitas Antibakteri}

Pembuatan suspensi bakteri Staphylococcus aureus dan Propioni bacterium acnes : Inokulum bakteri yang telah diinkubasi selama 24 jam diambil beberapa ose kemudian disuspensikan dalam TSB cair. Suspensi dikocok dan kekeruhannya disetarakan dengan standar kekeruhan 0,5 McFarland (NCCLS, 2003).

Penyiapan larutan ekstrak : Konsentrasi ekstrak daun pala disiapkan dari konsentrasi $0,1 \%, 0,3 \%$ dan $0,5 \%$ untuk bakteri Staphylococcus aureus . Kosentrasi ekstrak daun pala dibuat dengan cara melarutkan masing-masing $0,01 \mathrm{~g}, 0,03 \mathrm{~g}, 0,05 \mathrm{~g}$ ekstrak dalam 10 mL DMSO 1\%. Kemudian konsentrasi ekstrak daun pala disiapkan dari konsentrasi 10\%, 25\% dan 50\% untuk bakteri Propionibacterium acnes. Konsentrasi ekstrak daun pala $10 \%$ dibuat dengan cara melarutkan masing-masing $1 \mathrm{~g}$, 2,5 g, 5 g ekstrak dalam $10 \mathrm{ml}$ DMSO 10\%.

\section{Pengujian Konsentrasi Hambat Minimum (KHM)}

Larutan ekstrak daun pala yang telah dibuat dalam konsentrasi $0,1 \%, 0,3 \%$ dan $0,5 \%$ yang telah dilarutkan dalam DMSO $10 \%$ diambil masing-masing sebanyak 2 $\mathrm{mL}$, kemudian dimasukan kedalam cawan petri terpisah yang telah berisi media tryptic soy agar (TSA) yang sudah diinkubasi dan sudah dalam keadaan dingin. Setelah itu, diteteskan sebanyak $0,2 \mathrm{ml}$ bakteri dan diratakan dengan ose steril, lalu diinkubasi selama 24 jam pada suhu $37^{\circ} \mathrm{C}$, kemudian diamati pertumbuhan bakteri Staphylococcus aureus yang terbentuk.

Larutan ekstrak daun pala yang telah dibuat dalam konsentrasi $10 \%$, 25\% dan 50\% yang telah dilarutkan dalam DMSO $10 \%$ diambil masing-masing sebanyak $2 \mathrm{ml}$, kemudian dimasukan kedalam cawan petri terpisah yang telah berisi media brain heart infusion (BHI) yang sudah diinkubasi dan sudah dalam keadaan dingin. Setelah itu,diteteskan sebanyak $0,2 \mathrm{ml}$ bakteri dan diratakan oleh jarum ose steril lalu diinkubasi selama 24 jam pada suhu $37^{\circ} \mathrm{C}$, kemudian diamati pertumbuhan bakteri Propionibacterium acnes yang terbentuk. Kadar terkecil yang dapat menghambat pertumbuhan bakteri disebut konsentrasi hambat minimum (KHM) (Kumar, 2016).

Tabel 1. Formula Sediaan Sabun Cair (\% b/v)

\begin{tabular}{|c|c|c|c|c|c|c|c|}
\hline & $\begin{array}{c}\text { Kontrol } \\
(-)\end{array}$ & F1 & $\mathrm{F} 2$ & F3 & F4 & Kontrol (+) & Fungsi bahan \\
\hline $\begin{array}{l}\text { Ekstrak daun } \\
\text { pala }\end{array}$ & - & 2 & 4 & 8 & 10 & & Zat Aktif \\
\hline $\begin{array}{l}\text { Sodium Lauril } \\
\text { Sulfat }\end{array}$ & 5 & 5 & 5 & 5 & 5 & & Surfaktan \\
\hline $\mathrm{NaCl}$ & 5 & 5 & 5 & 5 & 5 & $\begin{array}{l}\text { Sediaan jadi yang } \\
\text { beredar di pasaran "JF } \\
\text { Sulfur" }\end{array}$ & Peningkat busa \\
\hline Propilenglikol & 5 & 5 & 5 & 5 & 5 & & Emolient atau pelembab \\
\hline Asam Sitrat & 0,5 & 0,5 & 0,5 & 0,5 & 0,5 & & Pengawet \\
\hline Aquadest & Ad & Ad & Ad & Ad & Ad & & Pelarut \\
\hline (ml) & 100 & 100 & 100 & 100 & 100 & & \\
\hline
\end{tabular}



Formulasi Sediaan Sabun Cair Pembuatan Formula Sabun Ekstrak Daun Pala

Formulasi sabun cair mengacu pada (Sari, 2018). Konsentrasi ekstrak daun pala mengacu pada (Rizal, 2017). Formula dapat dilihat pada Tabel 1. Ditimbang masingmasing bahan yang diperlukan sesuai yang tertera pada lampiran 3. Dimasukan sodium lauril sulfat kedalam beaker glass kemudian ditambahkan aquadest dan diaduk menggunakan batang pengaduk sampai larut. Lalu ditambahkan $\mathrm{NaCl}$ dan sedikit aquadest kemudian ditambahkan asam sitrat dan propilenglikol diaduk hingga larut.

Kemudian ditambahkan ekstrak daun pala yang telah dilarutkan oleh aquadest, diaduk hingga homogen. Setelah semua bahan sudah tercampur lalu dicukupkan dengan aquadest hingga $100 \mathrm{ml}$. Sabun cair dimasukan kedalam wadah bersih yang telah disiapkan. Pembuatan sabun ekstrak daun pala disesuaikan dengan masing-masing konsentrasi.

\section{Evaluasi Sediaan Sabun \\ Pengujian Organoleptis}

Uji organoleptik dilakukan untuk melihat tampilan fisik sediaan dengan cara melakukan pengamatan terhadap bentuk, warna dan bau dari sediaan yang telah dibuat (Depkes RI, 1995).

\section{Pengujian Homogenitas}

Uji homogenitas dilakukan dengan cara tiap formula sabun ditimbang sebanyak 0,1 gram diletakan pada objek glass, kemudian diamati.

\section{Pengujian Nilai pH}

Dilakukan dengan mencelupkan elektroda $\mathrm{pH}$ meter pada buffer 7 yang kemudian dimasukan kedalam setiap sediaan sabun yang akan diuji. Setelah elektroda tercelup, nyalakan $\mathrm{pH}$ meter kemudian didiamkan hingga layar pada $\mathrm{pH}$ meter menunjukan angka yang stabil (Septiani dkk, 2011).

\section{Penentuan bobot jenis}

Piknometer yang sudah bersih dan kering ditimbang dan dicatat beratnya. selanjutnya aquadest dan sabun masingmasing dimasukan kedalam piknometer dengan menggunakan pipet tetes sampai penuh. piknometer ditutup hingga volume cairan meluap, kemudian bersihkan cairan yang terbuang pada permukaan luar pikno dengan menggunakan tissue.

\section{Tinggi Busa}

Ditimbang 1 gram sabun kemudian dilarutkan dalam $10 \mathrm{ml}$ aquadest, kemudian diambil sebanyak $5 \mathrm{ml}$ sabun yang telah dilarutkan, kemudian dimasukan kedalam tabung reaksi lalu dikocok tabung reaksi dengan cara membolak-balikan tabung reaksi. Busa yang terbentuk kemudian diamati dan dicatat tinggi busa sabun (Rafika, 2017).

\section{Pengujian Lebar Daya Hambat (LDH)}

Metode pengujian yang digunakan adalah metode difusi kertas cakram. Inokulum bakteri diambil 0,2 $\mathrm{ml}$ dicampur kedalam $15 \mathrm{ml}$ TSA yang telah disterilkan dan didinginkan dengan cara aseptis, kemudian cawan petri digerakan melingkar untuk menyebarkan bakteri secara merata. Selanjutnya setelah agar memadat, diletakan kertas cakram yang mengandung larutan uji

: sabun ekstrak daun pala, kontrol positif dan basis. Kemudian diinkubasi selama 24 jam pada suhu $37^{\circ} \mathrm{C}$. Setelah diinkubasi, lalu diamati dan diukur LDH masing-masing cakram terhadap pertumbuhan bakteri Staphylococcus aureus . LDH diukur dari diameter zona bening yang terbentuk. Semakin besar LDH menunjukan semakin besar aktivitas antibakterinya (Anonim, 1993).

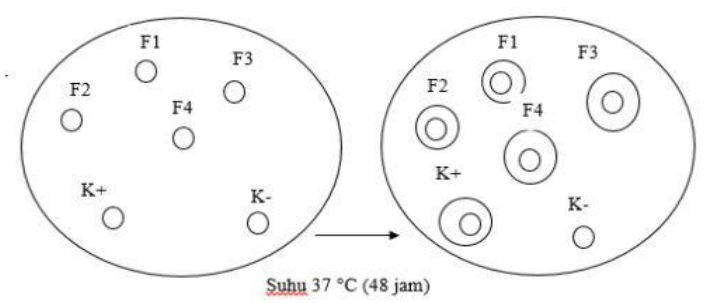

Gambar 1. Gambar Letak Kertas Cakram 


\section{Analisis data}

Untuk mengetahui pengaruh efektivitas berbagai konsentrasi sabun ekstrak daun pala sebagai antibakteri terhadap Staphylococcus aureus maka pengukuran lebar daerah hambat (LDH) dianalisis menggunakan rancangan acak lengkap (RAL) dengan 6 perlakuan (4 perlakuan dengan berbagai konsentrasi sabun ekstrak daun pala, 1 perlakuan dengan kontrol positif menggunakan sabun Jf Sulfur, dan 1 perlakuan dengan basis sabun sebagai kontrol negatif).

Jika terdapat perbedaan pada setiap kelompok maupun konsentrasi formula, maka diuji lanjut menggunakan Uji Duncan dengan menggunakan aplikasi SPSS 17.0.

\section{HASIL DAN PEMBAHASAN}

Determinasi tanaman yang telah dilakukan di Lembaga Ilmu Pengetahuan Indonesia (LIPI) Jalan Ir. H. Juanda No. 13, PO BOX 309 Bogor 16003, menunjukan bahwa tanaman yang digunakan dalam penelitian merupakan tanaman pala jenis Mysristica fragrans Houtt suku Myristicaceae.

Hasil ekstrak yang diperoleh adalah ekstrak kering berwarna hitam dengan rendemen $11,75 \%$. Hasil kadar air yang diperoleh dari serbuk dan ekstrak daun pala memenuhi persyaratan yaitu 5,6869 \%Dan $3,8648 \%$ kurang dari $10 \%$. Hasil kadar abu total yang diperoleh dari serbuk dan ekstrak daun pala memenuhi persyaratan yaitu $4,3343 \%$ dan $3,5689 \%$ kurang dari $10 \%$.

\section{Uji Fitokimia}

Tabel 2. Hasil Uji Fitokimia Serbuk dan Ekstrak Kering Daun Pala

\begin{tabular}{|c|c|c|}
\hline $\begin{array}{c}\text { Identifikasi } \\
\text { Senyawa }\end{array}$ & $\begin{array}{c}\text { Serbuk simplisia } \\
\text { daun pala }\end{array}$ & $\begin{array}{c}\text { Ekstrak kering } \\
\text { daun pala }\end{array}$ \\
\hline Alkaloid & + & + \\
\hline Flavonoid & + & + \\
\hline Saponin & + & + \\
\hline Steroid & + & + \\
\hline Tanin & + & + \\
\hline
\end{tabular}

Keterangan :

(+) mengandung senyawa fitokimia

(-) tidak mengandung senyawa fitokimia

\section{Konsentrasi Hambat Minimum}

Bakteri Staphylococcus aureus, konsentrasi $0,1 \%$ masih banyak bakteri yang tumbuh, konsentrasi $0,3 \%$ koloni bakteri mulai berkurang, sementara pada konsentrasi $0,5 \%$ koloni bakteri sudah tidak terlihat pada media agar. Sedangkan hasil KHM Ekstrak untuk bakteri Propioni bacterium acnes pada konsentrasi 10\%, 25\% dan $50 \%$ adalah negatif sehingga bakteri masih dapat tumbuh pada media agar.

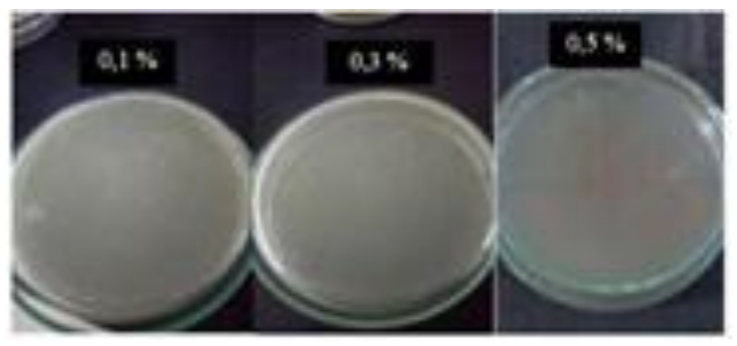

Gambar 2. Hasil Uji Konsentrasi Hambat Minimum terhadap bakteri

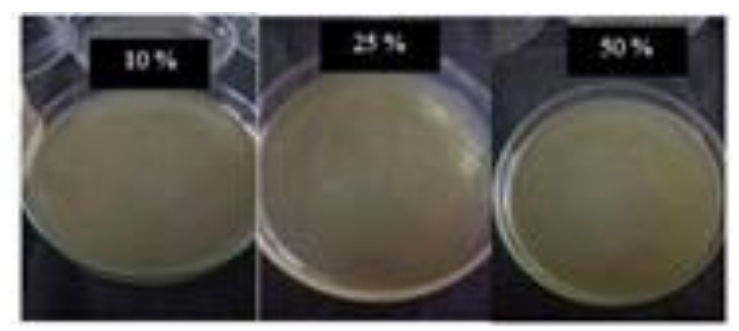

Gambar 3. Hasil Uji Konsentrasi Hambat Minimum terhadap bakteri Propionibacterium acnes

\section{Pengujan Organoleptis}

Tabel 3. Hasil evaluasi organoleptik sediaan sabun cair

\begin{tabular}{lccccc}
\hline Pengujian & F0 & F1 & F2 & F3 & F4 \\
\hline Aroma & Tidak & Khas & Khas & Khas & Khas \\
& berbau & pala & pala & pala & pala \\
Bentuk & Cair & Cair & Cair & Cair & Cair \\
Warna & $\begin{array}{c}\text { Bening } \\
\text { tidak }\end{array}$ & Coklat & Coklat & Coklat & Coklat \\
& & & & \\
& berwarna & & & & \\
\hline
\end{tabular}

Hasil evaluasi sediaan yang didapat memiliki bentuk yang cair, aroma yang didapat memiliki aroma yang khas dari daun pala. Sedangkan warna yang didapat pada sediaan sabun cair berwarna coklat, warna coklat pada sediaan sabun cair mengindikasikan adanya ekstrak daun pala 
yang berbeda dengan basis sabun yaitu bening tidak berwarna.

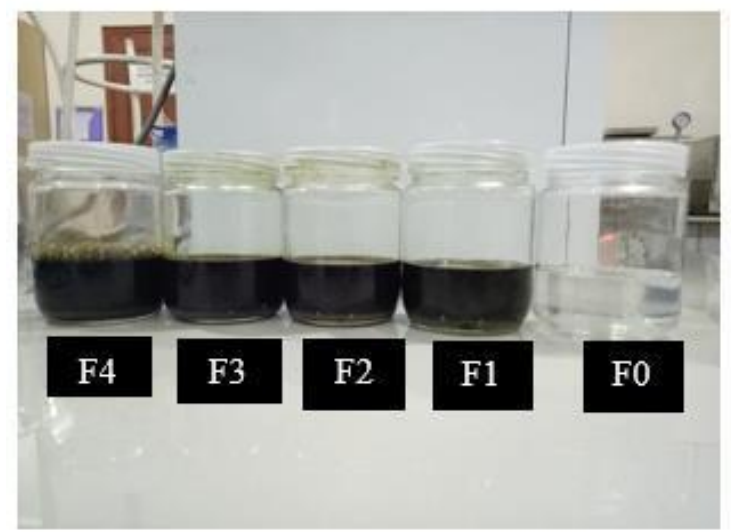

Gambar 4. Sediaan Sabun Cair Ekstrak Daun Pala.

\section{Pengujian Homogenitas}

Hasil evaluasi homogenitas sediaan sabun cair ekstrak daun pala yang didapat tidak semua homogen, karena masih adanya endapan didalam sediaan tersebut. Hal ini dikarenakan zat aktif yang digunakan berupa ekstrak kering, ekstrak tersebut tidak mudah larut sempurna dalam pelarut air. Selain itu, homogenitas dapat dipengaruhi dengan proses pengadukan dalam pembuatan formulasi.

\section{Pengujian Nilai pH}

Tabel 4. Hasil uji pH sediaan sabun cair ekstrak daun pala

\begin{tabular}{cc}
\hline Formula & Nilai $\mathrm{pH}$ \\
\hline F0 & 2,340 \\
F1 & 2,372 \\
F2 & 2,383 \\
F3 & 2,614 \\
F4 & 2,647 \\
\hline
\end{tabular}

Berdasarkan hasil pengujian $\mathrm{pH}$ pada sediaan sabun cair tidak memenuhi syarat, Penurunan $\mathrm{pH}$ bisa disebabkan oleh penambahan bahan penyusun sabun yaitu asam sitrat (Apriani, 2013). Secara umum, produk sabun cair memiliki $\mathrm{pH}$ yang cenderung basa, hal ini dikarenakan bahan dasar penyusun sabun cair yaitu $\mathrm{KOH}$, bersifat basa kuat.

Berdasarkan hasil yang diperoleh terbukti bahwa semakin tinggi konsentrasi ekstrak yang digunakan semakin tinggi daya busa yang didapatkan. Tinggi busa yang dihasilkan dari sediaan sabun disebabkan karena adanya kandungan saponin di dalam ekstrak daun pala, adapun karakteristik busa sabun dipengaruhi oleh beberapa faktor yaitu adanya bahan surfaktan, penstabil busa dan bahan-bahan penyusun sabun cair lainnya (Amin, 2006).

\section{Pengujian Lebar Daerah Hambat (LDH) Sediaan Sabun Cair}

Pengujian aktivitas antibakteri sediaan sabun daun pala dilakukan menggunakan Lebar Daerah Hambat (LDH) terhadap 6 perlakuan dengan 4 kali pengulangan, dilakukan pada 4 formula, kontrol positif dan negatif. Hasil dari uji antibakteri dapat dilihat pada gambar 5 .

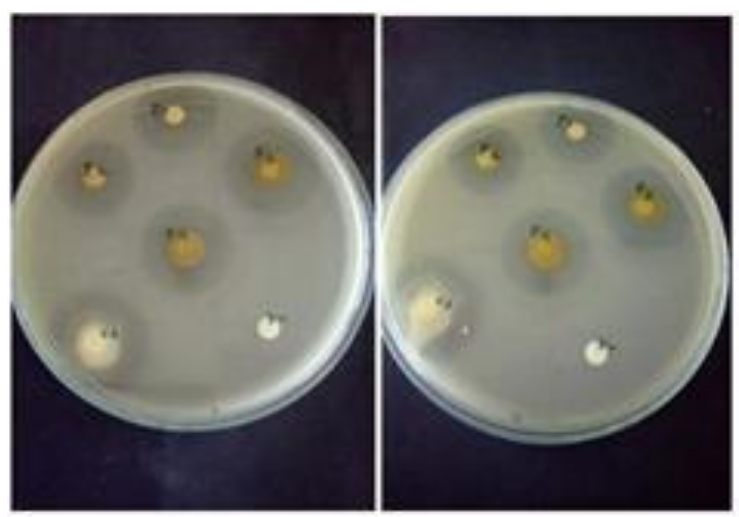

Gambar 5. Hasil Uji Lebar Daerah Hambat.

Tabel 5. Hasil nilai LDH Sabun Cair Ekstrak Daun Pala

\begin{tabular}{lccc}
\hline Formula & $\begin{array}{c}\text { Nilai rata- } \\
\text { rata LDH }\end{array}$ & SD & Kategori \\
\hline F1 $2 \%$ & 9,875 & 0,414 & Sedang (5-10) \\
F2 $4 \%$ & 10,500 & 0,353 & Kuat $(10-20)$ \\
F3 $8 \%$ & 10,750 & 0,250 & Kuat $(10-20)$ \\
F4 $10 \%$ & 11,875 & 0,216 & Kuat $(10-20)$ \\
K+ & 13,250 & 0,250 & Kuat $(10-20)$ \\
K- & - & - & - \\
\hline
\end{tabular}

Sumber kategori : Davis \& Stout (1971) 


\section{Pengujian Bobot Jenis}

Tabel 6. Hasil Bobot Jenis sediaan sabun cair ekstrak daun pala

\begin{tabular}{cc}
\hline Formula & Hasil BJ $(\mathrm{g} / \mathrm{ml})$ \\
\hline F0 (basis) & 1,0506 \\
F1 & 1,0506 \\
F2 & 1,0521 \\
F3 & 1,0664 \\
F4 & 1,0474
\end{tabular}

Bobot jenis sabun cair pada penelitan ini telah memenuhi standar dan mudah dibersihkan dengan air mengalir, karena memiliki bobot jenis yang mendekati dengan bobot jenis air.

\section{Pengujian Tinggi Busa}

Berdasarkan hasil pengujian terlihat dimana semakin tinggi konsentrasi ekstrak pada formula maka akan semakin besar lebar daerah hambat yang diperoleh. Zona hambat dari kontrol positif lebih besar dari semua konsentrasi sediaan, hal ini menunjukan bahwa kontrol positif berpengaruh terhadap bakteri Staphylococcus aureus sehingga aktivitas antibakterinya tegolong kuat. Sedangkan pada kontrol negatif tidak terdapat aktivitas antbakteri, hal ini menunjukan bahwa pengaruh aktivitas antibakteri yang diperoleh.

Tabel 7. Hasil pengamatan tinggi busa

\begin{tabular}{cc}
\hline Formula & $\begin{array}{c}\text { Tinggi Busa } \\
(\mathrm{mm})\end{array}$ \\
\hline F0 (basis) & 67 \\
F1 & 90 \\
F2 & 115 \\
F3 & 125 \\
F4 & 135 \\
\hline
\end{tabular}

Pada formula berasal dari zat aktif ekstrak daun pala.

Berdasarkan hasil analisis ragam dengan metode Rancangan Acak Lengkap (RAL) maka dapat dinyatakan bahwa sediaan sabun cair ekstrak daun pala memberikan pengaruh yang berbeda nyata terhadap pertumbuhan bakteri Staphylococcus aureus dengan terbentuknya daerah hambat disekitar kertas cakram yang berisi formula sabun cair ekstrak daun pala. Hasil analisis ragam dapat dilihat pada lampiran 9, berdasarkan hasil analisis ragam terlihat bahwa adanya perbedaan antara 6 jenis formula yang dilakukan terhadap lebar daerah hambat bakteri. Untuk mengetahui pengaruh antara formula maka dilanjutkan uji lanjut Duncan.

\section{KESIMPULAN DAN SARAN Kesimpulan}

Sediaan sabun cair ekstrak daun pala memiliki aktivitas antibakteri terhadap Staphylococcus aureus. Semakin tinggi konsentrasi ekstrak daun pala yang digunakan semakin besar nilai Lebar Daerah Hambat terhadap bakteri Staphylococcus aureus. Ekstrak daun pala tidak dapat menghambat pertumbuhan bakteri Propionibacterium acnes. Formula yang digunakan tidak memenuhi persyaratan $\mathrm{pH}$ sebagai sediaan sabun cair.

\section{Saran}

Perlunya reformulasi sediaan sabun cair agar menghasilkan $\mathrm{pH}$ yang memenuhi syarat, perlu dilakukannya uji panelis untuk mengukur tingkat kesukaan dari sediaan serta perlu dilakukannya uji viskositas untuk mengukur tingkat kekentalan dari sediaan.

\section{DAFTAR PUSTAKA}

Amin, H. (2006). Kajian penggunaan kitosan sebagai pengisi dalam pembuatan sabun transparan. Fakultas Perikanan dan Ilmu Kelautan Institut Pertanian Bogor.

Anonim. (1993). Penapisan Farmakologi, Pengujian Fitokimia dan Pengujian Klinik. Kelompok Kerja Ilmiah Pengembangan dan Pemanfaatan Obat Bahan Alam.

Apriani, D,. (2013). Formulasi Sediaan Sabu Mandi Cair Minyak Atsiri Jeruk Nipis (Citrus aurantifolia) dengan 
Cocamid DEA sebagai surfaktan. Skripsi Universitas Muhammadiyah Surakarta, Surakarta.

Chomnawang, M.T., Suvimol surrasmo, Veena S. Nukoolkarn, dan Wandee Gritsanapan. (2007). Effect of Garcinia mangostana on inflammations caused by Propionibacterium acnes.

Fitoterapia. Vol.78.(6): 401-408.

Davis \& Stout. (1971). Disc Plate Method of Microbiologycal Antibiotic Essay. Journal Microbology Vol 22 no.4.

Depkes, RI. (1985). Cara pembuatan simplisia. Direktorat Jendral Pengawasan Obat dan Makanan. Jakarta.

Depkes, RI. (1995). Materia media edisi V. Direktorat Jendal Pengawasan Obat dan Makanan. Jakarta.

Depkes, RI. (2000). Parameter standar umum ekstrak tumbuhan obat. Cetakan I. Direktorat Jendral Pengawasan Obat dan Makanan, Direktorat Pengawasan Obat Tradisional. Jakarta.

Dipiro J.T., Talbert R.L., Yee G.C., Matzke G.R., Wells B.G., and Posey L.M., (2009). Pharmacoterapy A phatophyciologic approach 7th edition, Mc Graw Hill, New York.

Hanani, E. (2015). Analisis fitokimia. penerbit buku kedokteran EGC. Jakarta.

Hernani, Bunasor, T.K,. dan Fitriati. (2010). Formula sabun transparan antijamur dengan bahan aktif ekstrak lengkuas (Alpinia galanga L. Swartz.). Bul. Litro. Vol.21(2) : 192-205.

Kumar, S. (2016). Essentials of Microbiology. Jaypee Brothers Medical Publisher, New Delhi. pp. 560-561.

NCCLS. (2003). Method for Delution Antimcobial Susceptibility Test dor Bacteria That Grow Aerobically. Approve Standard 6.

Parekh, J. dan Canda, S. (2006). In Vitro Antimicrobial Activity of Trata Natans
L. Fruit rind Extracted in different solvent. Gujarat : Saurashtra University

Poeloengan, M, \& Pratiwi, P. (2010). Uji aktivitas antibakteri ekstrak kulit buah manggis (Garcinia mangostana Linn). Media penelitian c dan Pengembangan kesehatan, 20(2): 6569.

Rafika, Sari. (2017). Pengujian aktivitas antibakteri sabun cair dari ekstrak kulit daun lidah buaya. Pontianak: universitas TanjungPura. 4(3).

Rizal, Fakhraina Yamami. (2017). Uji aktivitas antibakteri ekstrak etanol daun pala terhadap Escherichia coli dan Staphylococcus aureus Skripsi sarjana fakultas farmasi : Universitas Sumatera Utara.

Sari, R. K. (2018). Formulasi dan Uji Daya Hambat Sediaan Sabun Cair Kombinasi Ekstrak Daun sirih dan Kopi Robusta. Skripsi sarjana fakultas farmasi : Universitas Pakuan Bogor

Sarlina, Abdul Rahman Razaq, dan Muhamad Rinaldhi Tandah. (2017). Uji Aktivitas Antibakteri Sediaan Gel Ekstrak Daun Sereh (Cymbopogin nardus L. Rendle) terhadap bakteri Staphylococcus aureus Penyebab jerawat. Jurnal farmasi galenika Vol. 3(2) : 143-149.

Septiani, Shanti. Wathoni, Nasrul dan Mita, Soraya R. (2011). Formulasi Masker Sediaan Gel dari ekstrak etanol biji melinjo (Gnetum gnemon). Bandung : Universitas Padjajaran.

Suryana, S., Yen Yen Ade Nuraeni, dan Tina Rostinawati. (2017). Aktivitas Antibakteri Ekstrak Etanol dari lima tanaman terhadap bakteri Staphylococcus epidermidis dengan metode Mikrodilusi M7-A6CLSI. IJPST. Vol.4(1): 1-9. 